\title{
ESTIMATING ECONOMIC LOSSES DUE TO PASTURE WEEDS
}

\author{
G.W. BOURDÔT and D.J. SAVILLE
}

\author{
AgResearch Ltd, PO Box 60, Lincoln
}

Corresponding author: graeme.bourdot@agresearch.co.nz

\begin{abstract}
A method is presented for estimating the economic loss sustained by a pastoral industry due to a non-palatable herbaceous weed. The method requires monthly estimates of weed ground cover and dry matter produced by non-infested pasture along with the per annum production revenue and an estimate of the percentage of the industry's pasture-land infested by the weed. Applied to giant buttercup (Ranunculus acris L.) in dairy pastures in New Zealand the method estimated the national economic loss due to this weed to be NZ \$118 million in the 1999-2000 year.

Keywords: Giant buttercup, Ranunculus acris L., dairy pasture, milk solids, opportunity cost.
\end{abstract}

\section{INTRODUCTION}

Weeds are important economically because they reduce agricultural output and/or add to the costs of production. However, data on the productivity losses and costs of control for specific weeds have only rarely been collected, both in New Zealand (Anon. 1982) and internationally (Auld et al. 1987; Vere \& Auld 1982). Without these data agriculturalists cannot determine the costs and benefits of weed control or the economic level of weed control in a given situation (Bourdôt \& Saville 1990; Popay et al. 1989). Furthermore, without such data on a regional or national scale, scientists and research funding bodies can neither prioritize weed research programs nor objectively allocate funds between weed research and other research fields. Thus decisions on the management of weeds and the funding of research on weeds are being made in the absence of objective information.

The lack of this information is due, in part, to the wide variety of ways in which weeds may impact on agricultural production and the difficulty of quantifying these effects. However, for pasture weeds that are not eaten by grazing animals, the proportional reduction their current populations cause to potential productivity can be considered to be equal to the proportion of land they currently cover. Using this concept, a method has been developed for estimating the national loss in revenue (opportunity cost) to an industry from a nonpalatable pasture weed. The method was initially used to estimate the opportunity cost of Ranunculus acris L. (giant buttercup) to New Zealand's dairy industry (Bourdôt et al. 2002). In this paper we generalize the procedure to include any non-palatable pasture weed. In essence, a weighted mean annual percentage loss in pasture dry matter production in a paddock infested by the weed, based on measured weed ground cover data, is scaled up to estimate the loss in industry revenue at district, regional and national scales.

\section{METHOD}

For a pasture weed that is not eaten by grazing livestock under typical grazing management scenarios, the percentage loss it causes in the potential annual dry matter production of infested pasture in a district or region, $d(\mathrm{t} / \mathrm{ha})$, can be written as

$$
d=\frac{\sum p_{i} c_{i}}{\sum p_{i}}
$$

where $p_{i}$ is the average pasture production in the absence of the weed $(\mathrm{t} / \mathrm{ha})$ in the region or district in the $i$ th month of the year, and $c_{i}$ is the average $\%$ ground cover of the weed 
in an infested paddock in the region or district in the $i$ th month. Pasture production data used for feed-budgeting purposes in the district or region will provide adequate estimates of $p_{i}$. Estimates of $c_{i}$ can be obtained by monthly sampling of the weed's ground cover in paddocks chosen at random from the infested paddocks in the district or region.

Ideally, $p$ and $c$ would be estimated for each district or region independently, but resource constraints may restrict these estimates to one typical district or region. In this case it is necessary to assume that the seasonal growth patterns of pasture and the weed are similar in all districts and regions.

The weighted mean given by Equation (1) is a conservative expression for the true mean annual percentage loss in pasture production in infested paddocks in the district or region because it accounts only for the pasture directly excluded by the weed, ignoring any possible reductions in the productivity and utilisation of pasture plants in the neighbourhood of the weed plants. It also accounts neither for any detrimental effects of the weed on the quality or quantity of the animal product that may result from ingestion and/or coming into contact with the weed, nor the costs of current control operations.

The percentage loss in farmer revenue in a district or region due to the weed, $r$, can be written as

$$
r=d \times \frac{a}{100}
$$

where $a$ is the percentage of pasture paddocks used by the industry concerned in the district or region that are infested by the weed.

The opportunity cost of the weed in the region or district, $L$ (NZ \$), can then be written as

$$
L=\frac{r}{100-r} \times R
$$

where $R$ is the total annual revenue (NZ \$) received by farmers from the sale of product in the region or district. The national opportunity cost of the weed to the industry is the sum of the individual values of $L$ for all of the infested regions and/ or districts.

\section{RESULTS AND DISCUSSION}

Given satisfactory estimates of the model parameters, equation (3) gives an unbiased although conservative estimate of the revenue forgone annually by a pastoral industry in a district or region as a result of current infestations of the weed. The model is robust in an ecological sense in that it takes account (in equation (1)) of the fact that both pasture dry matter production, $p$ and weed cover, $c$, vary continuously throughout the year, and that weed cover may follow a different seasonal pattern to pasture dry matter production. For example, a weed that peaks in ground cover at a time of year when pasture production is low, will be assessed, correctly, as having a lower impact on annual pasture production than a weed that has the same average annual ground cover, but that peaks in cover at the same time as pasture production is at its maximum.

To illustrate the key aspects of the method, the results of an analysis conducted recently for giant buttercup (Ranunculus acris L.) in dairy pastures in New Zealand (Bourdôt et al. 2002) are considered. Each of the three equations is examined in turn.

Weed-free pasture dry matter production, $p$, on an average dairy farm in the Takaka valley, Tasman District, follows a pronounced seasonal pattern peaking in November and again in April (Fig. 1). The ground cover of giant buttercup in an average infested dairy pasture in Takaka follows a similar pattern, peaking also in November but with a less pronounced autumnal peak in April (Fig. 2). Using these monthly data in equation (1), the weighted mean annual loss in dairy pasture dry matter production during the milking season in Takaka (mid-August to mid-May), $d$, is $33.2 \%$. In the absence of cover data for other infested districts and regions, we assume that $d$ is also $33.2 \%$ in these areas (Table 1). 


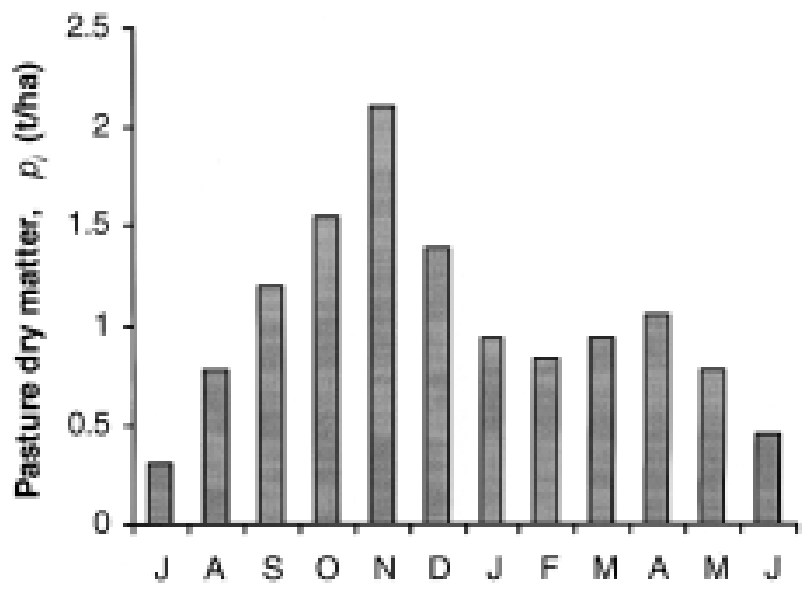

FIGURE 1: Seasonal pattern in pasture dry matter production, $p_{i}$, for weed-free pastures in the Takaka valley, Tasman District. Data from Denis Crone, Ministry of Agriculture and Forestry, Richmond, New Zealand as given in Bourdôt et al. (2002).

The percentage of dairy paddocks in the Tasman district currently infested by giant buttercup, $a$, estimated by local dairy farmers and ourselves, is $30 \%$. For the other regions, $a$ was estimated by regional council staff and consultants to the dairy industry, and varied from 5 to $35 \%$ (Table 1). The result was a range of losses in dairy farmer revenue, $r$, (equation (2)) due to giant buttercup from $1.7 \%$ in the South Auckland region to $11.6 \%$ in Taranaki (Table 1).

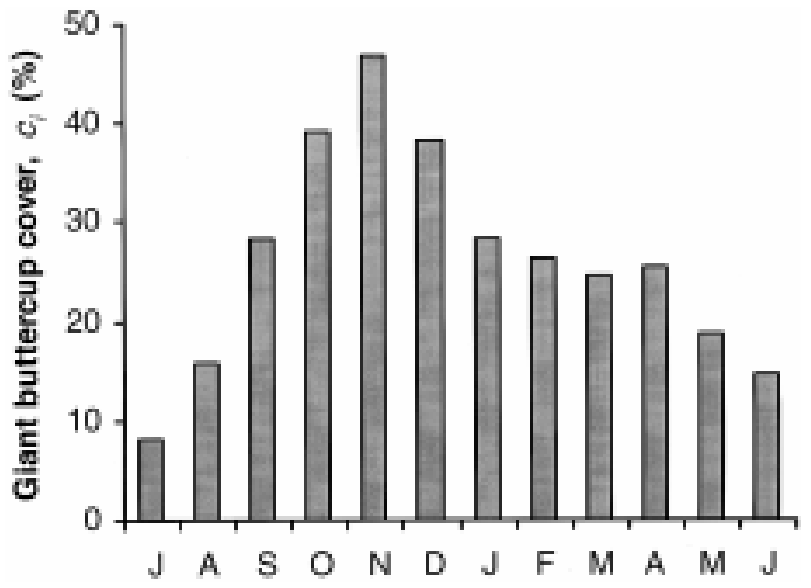

FIGURE 2: Seasonal pattern in the percentage of ground covered by giant buttercup (Ranunculus acris $\mathrm{L}$.), $c_{i}$, in a typical dairy pasture paddock infested by the weed in the Takaka valley, Tasman District. From Bourdôt et al. (2002). 
The last step in estimating the opportunity cost for each of the three infested regions and three districts was to obtain the current regional and district revenues received by dairy farmers, $R$. These values were derived from dairy farming statistics for the 19992000 milking season as the product of total milk solids (MS) produced per region or district and the price received; $\$ 4.50 / \mathrm{kg}$ MS (Bourdôt et al. 2002). Applying equation (3), the opportunity cost of current infestations, $L$, of giant buttercup range from $\$ 1.1$ million p.a. in the Hawke's Bay region to $\$ 86$ million p.a. in the Taranaki region (Table 1). The sum of the opportunity costs for all regions infested by giant buttercup is the national opportunity cost of the weed to the NZ dairy industry; $\$ 118$ million p.a.

TABLE 1: Outputs from the model described by Equations 1 - 3 and estimation of the national opportunity cost of giant buttercup (Ranunculus acris) to the New Zealand dairy industry. Parameter values were taken from Bourdôt et al. (2002).

\begin{tabular}{|c|c|c|c|c|c|}
\hline $\begin{array}{cc}\text { Infested } & \\
\text { region } & \\
\text { or } & \text { pro } \\
\text { district } & \text { inf } \\
& \\
& \text { mil }\end{array}$ & $\begin{array}{l}\% \text { loss in } \\
\text { pasture } \\
\text { luction in an } \\
\text { sted paddock } \\
\text { uring the } \\
\text { king season }{ }^{1} \\
\quad\end{array}$ & $\begin{array}{l}\% \text { land } \\
\text { area } \\
\text { infested } \\
\text { by the } \\
\text { weed } \\
a\end{array}$ & $\begin{array}{c}\% \text { loss in } \\
\text { revenue } \\
r\end{array}$ & $\begin{array}{c}\text { Annual revenue } \\
\text { from milk } \\
\text { solids } \\
\text { (NZ\$ million ) } \\
R\end{array}$ & $\begin{array}{c}\text { Opportunity } \\
\text { cost } \\
\text { (NZ\$ million) } \\
L\end{array}$ \\
\hline Sth Auckland & 33.2 & 5 & 1.7 & 1182 & 20.0 \\
\hline Hawke's Bay & 33.2 & 10 & 3.3 & 33 & 1.1 \\
\hline Taranaki & 33.2 & 35 & 11.6 & 653 & 86.0 \\
\hline Sth Wairarapa & 33.2 & 10 & 3.3 & 44 & 1.5 \\
\hline Horowhenua & 33.2 & 10 & 3.3 & 55 & 1.9 \\
\hline Tasman & 33.2 & 30 & 10.0 & 65 & 7.2 \\
\hline Total & & & & 2033 & 118 \\
\hline
\end{tabular}

${ }^{1}$ From equation (1).

${ }^{2}$ From equation (2)

${ }^{3}$ From equation (3).

The validity of these estimates of the opportunity cost, $L$, for the regions and districts other than Takaka, and hence also for the national estimate, rests on the assumption that the annual percentage loss in pasture dry matter production, $d$, is the same as Takaka in all districts and regions. In the absence of data for pasture dry matter production $p$, and giant buttercup ground cover $c$, for these other areas, making this assumption is a reasonable and necessary step to arrive at an estimate for the whole industry.

A further assumption inherent in this analysis is that the commodity price (here $\$ 4.50 / \mathrm{kg}$ MS) is constant throughout the year. For commodities with a seasonally fluctuating price, equation (1) would need to be replaced by

$$
d=\frac{\sum p_{i} v_{i} c_{i}}{\sum p_{i} v_{i}}
$$

where $v_{i}$ is the commodity price for month $i$ and $d$ becomes the $\%$ loss in revenue in an infested pasture. Equations (2) and (3) would remain unchanged.

In the example given here, we have taken no account of the fact that the rate of conversion of pasture dry matter to milk solids varies throughout the year, or of the effects of making hay or silage. These matters have been discussed in Bourdôt et al. (2002), where the effects of feed conservation on the estimated opportunity cost were 
shown to be relatively small. For example, if $20 \%$ of the land area was shut for silage from mid September until mid October, and $20 \%$ of uninfested land was shut for hay from mid November until the end of January, the national opportunity cost increased from $\$ 118$ million to $\$ 126$ million, due solely to the hay-making.

\section{REFERENCES}

Anon. 1982: The estimated costs of weeds to the agricultural sector of the New Zealand Economy - a discussion paper prepared by Monsanto New Zealand Limited. 14 p. Auld, B.; Menz, K.; Tisdell, C. 1987: Weed Control Economics. Academic Press, London. $177 \mathrm{p}$.

Bourdôt, G.W.; Saville, D.J. 1990: Calculating the economics of weed control. Proc. 43rd N.Z. Plant Prot. Conf.: 258-261.

Bourdôt, G.W.; Saville, D.J.; Crone, D. 2002: Dairy production losses due to giant buttercup (Ranunculus acris L.) in New Zealand. N.Z J. Agric. Res. Submitted 1 March 2002.

Popay, A.I.; Barlow, N.D.; Bourdôt, G.W. 1989: Economics of controlling Ranunculus acris in New Zealand dairy pastures. Brighton Crop Prot. Conf. - Weeds: 943-948.

Vere, D.T.; Auld, B.A. 1982: The economics and costs of weeds - a review. The 6th Aust. Weeds Conf:: 99-106. 